\title{
A FEBRASGO no Ano 2000
}

Estamos próximos do terceiro milênio. Alguns povos e religiões, como os chineses e israelitas, entretanto, já estão no quinto; outros, como os muçulmanos, na metade do segundo. A FEBRASGO contabiliza apenas 40 anos de existência. São quarenta anos de uma história conhecida, porém recente. Muitos vivenciaram a fundação da entidade que hoje nos une e agrega. Inúmeros colegas, que nos antecederam, colaboraram e deram o melhor de si, para que a FEBRASGO assumisse o papel de destaque que desfruta atualmente nos cenários nacional e internacional. A eles, devemos eterno reconhecimento.

Neste quadragésimo primeiro ano da era FEBRASGO gostariamos que maior número de colegas se juntasse a nós. Para isto se tornar realidade é necessária a colaboração de todos, sensibilizando os nossos pares, seja no seu ambiente de trabalho, seja nas faculdades, estimulando-os e mostrando-lhes as inúmeras vantagens do associativismo.

Gostariamos que o ano 2000 se tornasse o ano do grande crescimento associativo da FEBRASGO. Todos, sem dúvida, ganharão com isto. Para atingirmos esta meta dependemos do empenho e do trabalho de cada um.

Sua participação é fundamental!!!

\section{A DIRETORIA}

P.S.: Estamos remetendo o segundo "porta-revista", para que FEMINA e RBGO tenham um albergue adequado em sua estante e estejam sempre acessiveis quando necessário. 